TURIZAM

Volume 16 , Issue 4

$152-169$ (2012)

\title{
Integration of Environmental Aspects in Tourism Higher Education: the Hotel Managers' Point of View
}

\author{
Gul Gunes*, Gulcin Karakoc**, Canan Bastemur*** \\ Received: September 2012 | Accepted: November 2012
}

\begin{abstract}
Our environment and our society is continually dynamic. Courses such as hotel management, hygiene, food and beverage, front office are essential for the tourism sector. Besides, concern for environmental issues is one of the key components of higher education for tourism. This study presents a critical review of environmental aspects in higher education for tourism in Turkey. Because the demand for vocational schools (two-year colleges) is more than that for faculties, there are more vocational schools than four-year faculties in Turkey. Their curriculum was researched and determined to lessons about the environment. In the scope of this study; a questionnaire was conducted on managers of blue flag hotels to learn their opinion about the sector. According to these reviews, the importance of environmental education in higher education was emphasized.
\end{abstract}

Key words: Tourism, Education, Turkey, Environmental Aspects, Hotel Manager

\section{Introduction}

Tourism is a dynamic, evolving, consumer-driven force and is the world's largest industry, or collection of industries, when all its interrelated components are placed under one umbrella: tourism, travel; lodging; conventions, expositions, meetings, events; restaurants, managed services; assembly, destination and event management; and recreation. Tourism plays a fundamental role in framing various services that hospitality companies perform.

The leading international organization in the field of travel and tourism, the World Tourism Organization (WTO), is vested by the United Nations with a central and decisive role in promoting the development of responsible, sustainable, and universally accessible tourism, with the aim of contributing to economic development, international understanding, peace, prosperity, and universal respect for and observance of human rights and fundamental freedoms. In pursuing this aim, the organization pays particular attention to the interests of the developing countries in the field of tourism (Walker, 2009). The World Tourism Organization's definition of tourism is "the activities of persons travelling to and staying in plac-

* Department of Tourism and Hotel Management, Atilim University, 06836 Golbasi-Ankara/Turkey, Corresponding author: ggunes@atilim.edu.tr

** Gazi University, Institute of Social Sciences, Business Administration Programme, Ankara-Turkey

*** Department Head of Tourism and Hotel Management, Kastamonu University, Kastamonu-Turkey 
es outside their usual environment for not more than one consecutive year for leisure, business, and other purposes."

The Anatolian plateau is one of the cradles of civilization and has hosted many people throughout history. In addition to being one of the conventional mass tourism destinations in the Mediterranean and Aegean regions, Turkey offers visitors her cultural and historic assets. As a Mediterranean country, it has an advantage in this region due to its history, culture, art, natural beauty, gastronomy, folklore and people (DPT, 2007). This industry has an important position with respect to sustainability, climate, the existence of natural resources, and historical assets. Besides traditions and customs, the hospitality of the Anatolian people is an important aspect of tourism in Turkey. There are a number of other factors including a young and dynamic population, being a bridge between East and West, representing the exoticness of the East and having more modern and equipped accommodation facilities than other competitive countries in the Mediterranean (Bircan, et al., 2OIO).

Europe region, in which Turkey is located according to UNWTO (United Nations World Tourism Organisation), has found itself in a recovery period after the economic crisis. From the perspective of tourism, Europe recovered itself slower than other regions because of economic uncertainty. On the other hand, some large destinations in Europe region such as Turkey and Germany and some emerging destinations such as Balkans and South Caucasus have revealed remarkable results. In terms of international tourist arrivals, the share of Turkey is $5.7 \%$ with 27,000 arrivals within Europe region in 20IO. In terms of international tourism receipts Turkey generated 20.807 million US Dollars and has 5.I\% share from all Europe for the same year. Growth rates of destinations in Europe show that Israel (+2I\%), Malta (+I3\%), and Turkey (+6\%) achieved results significantly above average (UNWTO, 2OII). In 2OII, the robust growth of international tourist arrivals in Southern and Mediterranean Europe (I9\% share of world tourism) was mostly driven by the larger destinations: Greece (+IO\%), Turkey (+9\%), Portugal (+9\%), Croatia (+9\%), Spain (+8\%) and Italy (+6\%). Additionally, Turkey moved up one position to sixth in the "World's Top Tourism Destinations" (UNWTO, 2OI2).

Considering tourism as an economic asset in Turkey, some tourism related options are now outside the scope of conservation. Lack of social consciousness has also been effective in this process. However, several environmentally-concerned organizations have recently engaged in activities aiming at the conservation of cultural and natural assets, not only to ensure social awareness in this regard but also to fight against the decisions violating relevant regulations in the field. The conservation of natural and cultural assets can only be made possible by means of economic, political, and judicial instruments.

Before discussing environmental education in detail, environment and environmental education should be defined. Environment is the sum of living and non living things that surround an organism or group of organisms. It includes all elements, factors and conditions that have some impact on growth and development of certain organism. Environmentalism, on the other hand, is a very important political and social movement with the goal to protect the natural environment by emphasizing importance of nature role in protection of the environment in combination with various actions and policies oriented to nature preservation. In this context environmental education should have some major goals. These goals include:

- reducing world consumption

- reducing and cleaning up all sorts of pollution

- emphasis on clean, alternative energy sources

- $\quad$ sustainable use of water, land and other scarce resources

- conserving existing endangered species conservation of biodiversity (Haluzan, 2OI2). 
Environmental education is becoming much more important day by day due to the protection all of these details by law. The role of education in conservation and in addressing the rapidly increasing environmental problems, while improving the environment, is wellknown today. According to the Turkish constitution, everyone has the right to live in a healthy and balanced environment. Protection of environmental health, prevention of environmental pollutions and development of the environment are the duty of the State and every citizen (Vlavianos-Arvanitis, 1997).

Education for the environment is not only a task of formal education institutions, but also of civil organizations, media and local municipalities, which play a large role in increasing public awareness. Environmental problems recognize no artificial boundaries based on geography or ideology. For this reason, every nation must be assigned an international task for increasing public consciousness through media and education (Vlavianos-Arvanitis, 1998).

Turkish Hotels Federation emphasizes the importance of tourism education as follows (TUROFED Journal, 2009):

- Tourism education has to provide sufficient staff to the tourism sector.

- One of the main characteristics wanted in the enterprises operating at international market is qualified staff.

- Skilled and sophisticated people are needed not only at the production step but also at the marketing, advertisement and sales steps in the tourism sector. Especially international tourism market needs such staff.

As a result of all these aspects, tourism education becomes extremely important. Educated, skilled, knowledgeable and motivated people involved in the process of service delivery play an important role in efficiency of any tourism and hospitality business, including those in rural tourism and leisure. Positive attitude towards training and life-long learning among employees and family members should be encouraged, as they lie at the core of the total quality concept. People working in tourism and leisure sector - leaders, facilitators, trainers, managers and families - need a wide variety of knowledge and skills that can be obtained through formal and informal education and training. The possession of certain skills, however, is not enough; personal commitment and cultural interaction make a difference. Education and training should allow for the acquisition of multidisciplinary knowledge, which gives management and personnel the necessary flexibility and creativity required in these rapidly changing times. Specialized knowledge is too often a trap for creativity. Education and training should also ensure participants' action on the ground, and should be tailored to the needs of the people and rural areas. In addition to business skills, rural tourism development, micro- and small- scale rural tourism and leisure enterprise, anthropology, psychology and sociology, such themes as the following should also be covered (Verbole, 2005):

- Personal effectiveness and collaboration (in terms of personal development and change, learning styles, team building, conflict handling);

- Communication (multicultural, interpersonal, foreign languages, verbal and non-verbal);

- Management (in terms of decision making, problem analysis and solving);

- Leadership and human resource management;

- Consumer behaviour, public relations and visitor management. 
The term 'sustainability' in tourism implies that the tourism sector can continue to grow while enabling the sustainability of new tourism opportunities in a manner that its destinations and their districts can also satisfy the requirements of future generations.

The concept of sustainability - which means benefiting from resources without endangering the future - is very important. All over the world, people are concerned with the social injustice and environmental problems; they are becoming increasingly aware of the need for an approach in tourism which has fewer impacts and which is not damaging to the environment. They tend to support the initiatives aiming at local conservation and social development while adopting "green consumer" life styles and shifting from intensive consumptive habits to healthy ones. Because of such concerns, the interest in sustainable tourism and ecotourism has been increasing day by day (Eagles et al., 2002).

The anticipated growth and new trends observed in tourism have promoted the sector into such a strategic position that it may become the most important tool for the conservation of resources as well as for increasing the environmental consciousness of local people. These objectives can be achieved by generating financial resources, which are necessary for conservation of natural, historic and cultural assets by means of tourism, creating awareness and education programs for visitors and local communities (Beunders et al. 2007). Tourism affects countries and communities through its political, economic, social and cultural impacts on communities and nations. It can contribute to positive international relations and to national economies through direct foreign exchange earnings as well as through its significant multilayer effect.

Tourism education is the struggle of creating a change in manners to raise awareness of the community related with tourism, to bring qualified work force and managers up that are required by tourism sector (Hazar, 2002). In the following part of this paper, tourism education in the world and its stages are discussed.

Tourism can function well if there is harmony among several interacting institutions. Among these various institutions, universities and education centres play an important role as they take professional responsibility to educate the human resources needed for the tourism sector. Hence, the role of education institutions in tourism development is critical (Shrestha and Rayamajhi, 1997).

\section{Tourism Education in the World}

Schmelzkopf (2OO2) claims that tourism is not a discipline. Tourism has a multidisciplinary perspective; tourism is a business that has pleasure as its product. The author also states that tourism is a set of industries, and in order to understand tourism, its economic, political, ecological and cultural aspects should be examined. According to this definition, it can be concluded that different kinds of disciplines should be included in tourism education.

Tourism education systems may differ. According to Christou (I999), some emphasize vocational training through apprenticeships, while others develop an academic approach.

Presence of tourism programs in colleges and universities dates back to I92Os and include institutions in Austria and Switzerland. The first programs in Australia were developed in late I970s and were strongly influenced by developments in Europe. As of 1997 tourism was being offered as a first degree in three tertiary institutions and twenty three universities (Hall, 2008). 
If tourism education is to develop and continually meet the needs of an expanding and increasingly differentiated global industry, the program developers will need to seek out new ways of ensuring that graduates are able to demonstrate a breadth of management skills and have the ability to add value to organizations operating in the tourism environment. It is argued that three domains should emerge within tourism education:

- Generic degrees: These programs offer the interdisciplinary skills required for a broad understanding of the tourism industry.

- Functional degrees: These programs offer the student the functional expertise in a particular area of tourism. Due to the service-oriented nature of the tourism industry, often specialist skills are required in the areas of IT, marketing, planning and so on.

- Market/product -based degrees: These programs focus on the nature and development of particular niche products and markets which require specialist knowledge and expertise for their effective delivery (Dale and Robinson, 20OI).

As Aymankuy and Aymankuy (2002) stated in their study, there should be two kinds of education models for tourism sector. First one is the academic tourism education which directs country's tourism sector, implements programs by preparing national tourism policies and plans. The second one is the vocational tourism education. In this type, qualified staff is educated for businesses that comprise tourism sector. Furthermore, there are also two kinds of education systems -formal and mass education- in terms of their implementation. Formal education is a kind of education system that is given to the individuals in the same level and at determined ages according to the determined goals and it should be given in a school. Mass education is another kind of the education system that is given to individuals at different ages and in different levels by the help of the predetermined programs in the places where is required by the program (Hacioglu et al., 2008).

Moreover, Agaoglu (I99I) examined tourism education in four groups:

I. Public Tourism Education: Since tourism is an important economic factor, countries try to do their best in order to increase tourist arrivals to their own countries. Without any doubt, it can be said that one of the most important things for increasing this capacity is to educate public community. The case of providing community with tourism awareness by the help of media, several seminars, and conferences is defined as public tourism education.

2. General Tourism Education: This education model comprises tourism courses that are given in the general education system.

3. Vocational and Technical Tourism Education: Generally, 'tourism' is perceived as "hotel businesses" in most of the countries. This perception emerged when the first tourism school was opened under the name of "Hotel Management School" in I893. In due course, these schools have had the name of "Tourism Vocational School" and tourism schools have been separated into departments like hotel management, gastronomy and tourism vocational schools.

4. Academic Tourism Education: In this system, it is aimed to raise qualified employee for management positions in the tourism sector.

Tribe (2OO2) states those curricula for higher education in general and tourism in particular, are not well developed. According to Tribe, the curriculum is a whole educational experience packaged as a degree program and it aims to promote a balance between satisfying the demands of business and of the wider tourism society and world. 
Within the the tourism education in Europe vocational education is one of the most important pieces of the education puzzle. Because of its characteristics, tourism sector considerably values the vocational education. As Yazcayir and Yagci (2009) states, aim of vocational education institutions is to train qualified work power for vocational areas. Likewise, the basic goal of vocational tourism education is to deliver the vocational formation that is requested by the tourism sector (Avcikurt and Karaman, 20O2). Vocational education is an education process that equips individuals with necessary knowledge, skills and working habits and aims to improve the abilities of individuals in different ways (Hacioglu et al., 2008). The tourism education is trying to maintain some reforms in order to develop new education methods, to improve quality and to create a good relationship with the sector (Oncuer, 2006).

Today, the most notable improvement in tourism education is seen in United States of America in terms of the number of programs. Approximately 5000 undergraduate and graduate programs have been formed in the United States (Airey and Johnson, I999).

\section{Environmental Aspects in Tourism Education}

Rio Summit in 1992 led organizations such as UNESCO to reorient their concept of environmental education towards education for sustainability. The new concept of environmental education reflects that all fields related to the establishment of sustainable society, are the target of environmental education activities. Environmental education is necessary for the purpose of dealing with urgent environmental issues as well as taking a broad view (Environmental Education Project, 2OII).

Lockwood and Medlik (2OOI) emphasizes that concern for environmental issues is one of the most salient trends that will shape the environment in which the world's tourism and hospitality industry will prosper in the next 20 years. As rain forests disappear and evidence of global warming builds, it is becoming ever more difficult to ignore the impact of people on nature - and its impact on people. At this point, the question is not whether the industries and lifestyles will be changed to accommodate the environment, but how radically it must be changed, how quickly people should act, and how much it will cost for people. It is inevitable that this transition will be the hard one Topics for attention include air pollution, acid rain, loss of forests, depletion of the ozone layer, waste disposal, toxic chemicals in our food and water, soil erosion, mass extinction of species and pollution of beaches, oceans, reservoirs and waterways (Lockwood and Medlik, 2OOI).

Lockwood and Medlik (2OOI) explain the implications for tourism and hospitality as follows:

Demands for still more environmental controls are inevitable, especially in relatively pristine regions. 'Ecotourism' will continue to be one of the fastest growing areas of the tourism industry. The increasing dominance of high technology in our daily lives also promotes this trend. Rain forests, wilderness areas, the ocean and other unpolluted regions provide a unique and necessary chance to escape from keyboards and cell phones. Recycling, air quality, waste disposal, kitchen safety and other aspects of the workplace environment will be increasingly regulated and will require greater management attention and investment.

Tourism and environment create resource for each other. However, if environmental awareness cannot be created, then tourism industry will lead to negative environmental consequences and will threaten its own sustainability. As Barron and Prideaux (I998) explained, 
an effort to improve the standard of management through education is one approach to increase environmental awareness and the development of sustainable tourism development.

If tourism and hospitality management students can be persuaded that environmental issues are of fundamental importance, they could be effective agents of change. The curriculum of the program is not the only influence on students' perceptions of environmental issues. The learning outcomes must ensure the students can be critical, objective, well-informed and analytical about the subject matter (Wade, I999).

In her study on university students' perceptions about environmental education in U.K., Wade (1999) found out that a high percentage of students (46\%) see the environment as relevant to the hospitality management curriculum and they said that they need to be thoroughly informed.

As Tribe (20O2) states, the curriculum can be filled with various knowledge, skills, and attitudes, so tourism students take different educational journeys according to how their curriculum has been framed.

Basic training in ecology and environmental sciences, and also in the structure of the tourism industry, is available through a wide range of university courses. Few of them combine these two fields. There are also some university courses such as outdoor education, and parks, and recreation management. Again, few of these courses combine these fields with ecology and tourism (Buckley, 2009).

It is true that some progress has been made in environmental education at higher education level but it is clear that this progress is not sufficient. Chaineux and Charlier (I999) claim that academic training makes significant contributions to environmental issues with a great impact. They stated that academic education motivates youngsters in the first place and through them their parents to look at environmental problems.

Moreover, government policies can affect the style of education, and according to these policies, some insufficiencies may occur. For instance, if a government does not make environmental regulations in general, its education program does not emphasize environmental issues. In this kind of a situation, training necessities appear. While education is provided by institutions like schools and universities, training programs are conducted in the content of a job orientation or a project that has the aim of creating skilled labour force.

In Uganda, tourism was seen as an illegal activity since I994-the decline of Idi Amin's regime. Then, Uganda understood the importance of their wealth in wildlife and as a result need for training programs arose. In May 1995 a project was conducted. In order to provide labour force for the tourism industry and to raise awareness among local people and tourism industry related with the environmental wealth of Uganda (wildlife, ecotourism activities, and so on), training programs began to be conducted. The first training program aimed to build visitor satisfaction. The training program combined a one-week training workshop with a follow-up site visit for participants in order to provide supervision and this program also allowed participants discover possibilities of success simply through adoption of new techniques in the use of resources already existing in the nearby region (Victurne, 2000).

To summarize, sustainability, ecotourism, environmental-outdoor-recreational area and park management, training, wildlife education, conservation and government environmental policies are very important topics in tourism education (Tribe, 2002). 


\section{The Case of Turkey}

The beginning of tourism education in Turkey dates back to I95Os. In those years, courses were conducted in order to train waiters and chefs in Ankara and Istanbul (Agaoglu, I99I).

The most notable improvements related to tourism education in Turkey began with the foundation of Ministry of Tourism. In this period, tourism consulting groups were formed and some tourism education specialists were invited to Turkey in order to examine the situation.

The head of the Hotel Management School of Paris, M. Marcel Jeanne, is one these specialists. He examined Turkey's tourism sector and education, and gave the following comments (Agaoglu, I99I):

- Turkish hotels are not managed in compliance with the contemporary methods

- The vocation of hotel management is looked down on by the community

- The staffs of the hotels are not well-qualified and well-educated

- Hotel managers are deficient in vocational formation.

- Women generally don't prefer to be employed in this sector because of labour-intensive conditions

These comments urged Turkey to find solutions to get rid of these problems. Thus, it is understood that education is the most valuable thing for the effective management of the sector.

The tourism education in Turkey can be categorized as follows (The Final Report of The Conference on The Research of Academic Tourism Education, 2009):

I. Mass Education

- Public education

- Cultural education

2. Formal Education

a) Academic Tourism Education

- PhD degree

- MSc (MA) degree

- Undergraduate degree

- Associate degree

b) Diploma

- Vocational High Schools of Ministry of Education

c) Certificate

- Courses (Ministry of Tourism, Association of Turkish Travel Agencies - TURSAB)

- Certificate Programs

- Private Education Centres

- $\quad$ On the job training

- Public Education

Kusluvan and Kusluvan (2000) formed a table that reflects the structure of tourism and hospitality education in Turkey (Table I).

There are different approaches in tourism education in Turkey. In European countries, vocational education begins after the compulsory education. This compulsory education generally lasts for 9 years in European countries and it is $4^{+4+4}$ years in Turkey. In the world, tourism education is separated into several branches like hotel management, gastronomy, catering and tourism. On the other hand, tourism schools in Turkey operate under the title 
Table 1. Tourism and Hospitality Education in Turkey

\begin{tabular}{|l|l|l|l|l|}
\hline Level & Schools & Duration & Entrance & Outcome \\
\hline $\begin{array}{l}\text { Vocational } \\
\text { Training }\end{array}$ & $\begin{array}{l}\text { Vocational Tourism Train- } \\
\text { ing Centers }\end{array}$ & 7 months & $\begin{array}{l}\text { Primary and secondary school } \\
\text { drop outs are accepted through } \\
\text { written exam and interview }\end{array}$ & Certificate \\
\hline $\begin{array}{l}\text { Secondary school } \\
\text { level }\end{array}$ & $\begin{array}{l}\text { Vocational Tourism and } \\
\text { Hotel High School }\end{array}$ & 4 years & $\begin{array}{l}\text { Only primary school drop outs } \\
\text { are accepted through written } \\
\text { exam and interview }\end{array}$ & Diploma \\
\hline $\begin{array}{l}\text { Pre-undergraduate } \\
\text { level }\end{array}$ & $\begin{array}{l}\text { Tourism and Hotel Man- } \\
\text { agement Vocational High } \\
\text { Schools }\end{array}$ & $\begin{array}{l}\text { 2 years after any sec- } \\
\text { ondary schools }\end{array}$ & University entrance exam & Associate Degree \\
\hline $\begin{array}{l}\text { Undergraduate } \\
\text { level }\end{array}$ & $\begin{array}{l}\text { Tourism and Hotel Man- } \\
\text { agement Schools }\end{array}$ & $\begin{array}{l}\text { 4 years after any sec- } \\
\text { ondary schools }\end{array}$ & University entrance exam & Bachelor's Degree \\
\hline Postgraduate level & Tourism Management & $\begin{array}{l}\text { 2 years after a bache- } \\
\text { lor's degree }\end{array}$ & Written and oral exams & MS Degree \\
\cline { 2 - 5 } & Tourism Management & $\begin{array}{l}\text { Minimum 3 years after } \\
\text { a MSc degree }\end{array}$ & $\begin{array}{l}\text { Written and oral exams and } \\
\text { foreign language exam }\end{array}$ & PhD Degree \\
\hline
\end{tabular}

of "tourism" and they give hotel management education generally. In 2OIO-2OII education period, the number of tourism and hotel management high schools was II6 and the number of tourism education centres was 9. Total number of students was 33.479 (Directorate of Tourism and Trade Education, 2OII).

In Turkey, undergraduate program of tourism and hotel management (4 years) is delivered by 48 different universities. Quota for new students, who will register to this program during 2009-20IO academic year, was determined to be around 4500. Six new tourism and hotel management programs, one of which was an online program, were opened in the 2009-2OIO academic year and started to accept students (Academic Tourism Bulletin, 2009). There are 3I8 two year tourism programmes (Tourism and Hotel Management, Tourism and Travel Services, Catering, Tourism Animation, Tourism Guidance Departments) and 99 four year programmes (Travel Management and Tourist Guidance, Food and Beverage Management, Hospitality Management, Travel Management, Tourism Guidance, Hotel Management and Tourism Management Departments) in Turkey. 4 of two year programmes are online and IO8 of them are evening (second) education. 37 of four year programmes are evening education and 3 of all programmes are Open University (OSYM, 2OI2).

Aims of universities active in tourism programs are:

- Providing skilled personnel to the tourism sector,

- Establishing the connection between theory and practice through education,

- Contributing to the development of tourism industry,

- Strengthening friendship and brotherhood among people by improving love for nature and human,

- Increasing the knowledge and skills of those working in tourism enterprises,

- Promoting the place and importance of tourism in economic development,

- Raising awareness on tourism,

- Creating positive tourism consciousness among citizens and enabling tourism employees gain professional formation (TUROFED Journal, 2O09).

After the global economic crisis in 2008, tourism and travel management have been indicated as popular jobs in Turkey. Therefore, both interest in and significance of tourism pro- 
grams have been gradually increasing. As it was emphasized in the previous parts of this paper, environmental education is beneficial for the sustainability of the tourism sector.

Tourism education has not developed at the same rate as tourism did. The most valuable aspect of mainstreaming environment into tourism education is that while developing tourism studies or training programs, the educational institutes must analyze the needs of the country's tourism and in turn develop relevant programs (Shresta and Rayamajhi, 1997).

According to the Turkish Tourism Strategy-2O23 that is prepared by Ministry of Culture and Tourism in 2007, the vision of Turkish tourism is "with the adoption of sustainable tourism approach tourism and travel industry will be brought to a leading position for leveraging rates of employment and regional development and it will be ensured that Turkey becomes a world brand in tourism and a prime destination in the list of the top five countries receiving the highest number of tourist and highest tourism revenues by 2023 " and its educational strategy is determined as " tourism education shall target raising awareness on the existence and protection of national tourism assets and resources and leveraging the contribution of tourism to the national economy at highest possible extent" (Ministry of Tourism and Culture, 2007).

According to the year 2OII statistics, tourism education is given in 99 of I54 universities $(64 \%)$ of Turkey and 92 of 239 four year colleges. $72 \%$ of tourism education is delivered in two-year colleges (vocational higher education), $28 \%$ in four-year departments in universities (İAÜ, 2OII). It is not surprising that Turkey's tourism is under the control of mass tourism activities. However, Turkey has an enormous alternative tourism potential with its natural and cultural heritage. In Turkey's academic tourism education, it is gradually realized that tourism education should be integrated with environmental awareness/education in order to put forward this capacity. To analyse the integration of tourism education and environmental issues in different programs in Turkey, curricula of different private universities were reviewed via their web pages. Some courses related with environmental conservation in different undergraduate programs of private universities are given in Table 2.

Table 2. The courses of private universities related to environmental conservation

\begin{tabular}{|l|c|c|c|c|c|c|c|}
\hline University & $\begin{array}{c}\text { Alternative } \\
\text { Tourism }\end{array}$ & $\begin{array}{c}\text { Sustainable } \\
\text { Tourism }\end{array}$ & $\begin{array}{c}\text { Nature Pro- } \\
\text { tection and } \\
\text { Tourism }\end{array}$ & $\begin{array}{c}\text { Environment } \\
\text { and Alterna- } \\
\text { tive Tourism }\end{array}$ & $\begin{array}{c}\text { Tourism Policy } \\
\text { and Sustaina- } \\
\text { bility }\end{array}$ & Eco tourism & $\begin{array}{c}\text { Tourism and } \\
\text { environment }\end{array}$ \\
\hline Atılım & $\mathrm{X}$ & & $\mathrm{X}$ & $\mathrm{X}$ & $\mathrm{X}$ & \\
\hline Baskent & & & & & & & \\
\hline Beykent & & & & & $\mathrm{X}$ & $\mathrm{X}$ & \\
\hline Bilkent & & & & & & & \\
\hline Çag & & & & & & & \\
\hline Halic & & & & & & & \\
\hline İstanbul Arel & & & & & & \\
\hline Istanbul Ticaret & & & & & & \\
\hline Yasar & & & & & & \\
\hline
\end{tabular}

\section{Research Methodology}

This study was designed as a survey that combined qualitative and quantitative data. The qualitative data were collected by means of written documents, interviews with hotel managers, lecturers at universities and observation of the characteristics of the academic programs. The 
quantitative data were collected by a questionnaire administered to the blue flag hotels' managers or human resources managers. This study was conducted between June and November $2 \mathrm{OII}$ on blue flag accredited hotels in Turkey. In this time period, there were hotels with blue flag accreditation in Antalya, Didim, Kusadası, Izmir, Balıkesir, Bodrum, Mersin, and Marmaris. The subjects of the questionnaire are limited to general managers or human resources managers of 50 hotels due to time and money factors. The questionnaire was conducted in Aegean Region, which includes 50 blue flag hotels. Questionnaire forms were sent to subjects, but only 35 responses were received, despite several reminders. Scanning model has been used in this study. Efforts were made to determine the employers' point of view on the integration of environmental aspects with higher tourism education. The survey technique comprised the data collection method; in the mean time the views of a number of specialists (hotel directors and academics) were collected and the literature was studied. Later survey questions were prepared based on such data together with the information in the fields of tourism, environment and statistics. A pilot run was conducted on hotel managers, human resources managers and corrections were made on the questionnaire by using the feedbacks.

The questionnaire consisted of two parts: In the first part, the questions were about the employers. In the second part, there were questions related with hotel features, and their knowledge about environmental aspects. The Likert type scale-5, multiple-choice, sequencing, two-choice type questions were used and I7 questions were asked in total. Eight statements regarding integration of environmental aspects into higher education for tourism were answered by the hotel managers or human resources managers in Likert type scale as follows:

I - Totally disagree

2 - Disagree

3 - Partially agree

4 - Agree

5 - Totally agree

The questionnaire was conducted via e-mail and telephone conversations.

\section{Findings and Evaluation}

Only 35 of questionnaire forms were properly completed, unfortunately. Questionnaire data were analyzed in SPSS for Windows I7.O program. 0,63 value was calculated in the analyzed of Cronbach's Alpha reliability and on this basis this questionnaire is quite reliable (Ozdamar, 2003).

According to Table 3, 62.9\% of the subjects who participated in the survey is women, 37.I\% is men. $54.3 \%$ of the subjects is graduated. Regarding the years of experience in the firm, the highest rate is $40 \%$ for the 5 -IO years option. The rate of hotels that have over 400 beds is $42.9 \%$. All of the hotels participated in the survey have active practices about environment. There is no two-star hotel among the hotels participated in the survey. $42.9 \%$ of them are five-star hotels. The number of hotels that have had environmental practices for less than 5 years is more than twice of the number of those with more than II years. All of these hotels have some kind of accreditation; $94.3 \%$ has blue flag certification, $5.7 \%$ is environmentally friendly hotels.

According to Table 4, "Attention is paid to energy conservation in our hotel" is the statement that has the highest participation with the mean value of 4.7I. Statements with high 
Table 3. Survey findings

\begin{tabular}{|c|c|c|c|}
\hline & Groups & $f$ & $\%$ \\
\hline \multirow{2}{*}{ Gender } & Female & 22 & 62,9 \\
\hline & Male & 13 & 37,1 \\
\hline \multirow{4}{*}{ Education } & Two-Year Degree & 6 & 17,1 \\
\hline & Graduate & 19 & 54,3 \\
\hline & Master Degree & 7 & 20 \\
\hline & Others & 3 & 8,6 \\
\hline \multirow{3}{*}{ Duty Term of the Manager } & Less than 5 years & 12 & 34,3 \\
\hline & $5-10$ years & 14 & 40 \\
\hline & More than 11 years & 9 & 25,7 \\
\hline \multirow{3}{*}{ Bed Capacity } & $0-200$ & 12 & 34,3 \\
\hline & $201-400$ & 8 & 22,9 \\
\hline & More than 400 & 15 & 42,9 \\
\hline \multirow{6}{*}{ Star } & 1star & 6 & 17,1 \\
\hline & 2 star & 0 & 0 \\
\hline & 3 star & 3 & 8,6 \\
\hline & 4 star & 9 & 25,7 \\
\hline & 5 star & 15 & 42,9 \\
\hline & Boutique & 2 & 5,7 \\
\hline \multirow{2}{*}{$\begin{array}{l}\text { Presence of Environmental } \\
\text { Management Practice }\end{array}$} & Yes & 35 & 100 \\
\hline & No & 0 & 0 \\
\hline \multirow{3}{*}{$\begin{array}{l}\text { Duration of Environmental } \\
\text { Management Practice }\end{array}$} & Less than 5 years & 20 & 57,1 \\
\hline & $5-10$ years & 7 & 20 \\
\hline & More than 11 years & 8 & 22,9 \\
\hline \multirow{5}{*}{$\begin{array}{l}\text { Accreditation Practice of } \\
\text { the Hotels }\end{array}$} & ISO 14001 Environmental Management System & 12 & 34,3 \\
\hline & Facility with Blue Flag Certification & 33 & 94,3 \\
\hline & Environmentally Friendly Hotels & 2 & 5,7 \\
\hline & $\begin{array}{l}\text { TUI Holy Hotels with the Certification of the Best } \\
\text { Environmental Protection }\end{array}$ & 3 & 8,6 \\
\hline & None & 0 & 0 \\
\hline
\end{tabular}

agreement rates are "Our hotel is differentiated by the importance given to issues related to the environment and environmental management"(4.02), "Non-hotel companies are backed up related to education about environmental management given to employees" (3.42), "Hotel employees are given training in environmental management." (3.97). Statements with medium agreement are "The hotel staff is required to receive to training about environmental management during their university studies" and "Training in environmental management, human resources will be provided by employees" (2.85). In the survey, low agreement is measured with the statement "Issues about the environment and environmental management in Turkey are paid enough attention by the hotels" (2.54).

Moreover, according to other analyses that are not shown here, hotel managers participating in the survey examined the relationship between education levels and level of agreement with the statements. None of the statements give significant results. $4(4.33 \%$ and 5 (4.33\%) star hotels put the highest emphasis on environmental management education for 
Table 4. Distribution of the Statements about the Environment Protection Practices of the Hotels

\begin{tabular}{|c|c|c|c|c|c|c|c|c|}
\hline \multicolumn{2}{|c|}{$\begin{array}{l}\text { Distribution of the Statements about the Envi- } \\
\text { ronment Protection Practices of the Hotels }\end{array}$} & \multirow{2}{*}{$\begin{array}{r}\begin{array}{c}\text { Totally } \\
\text { Disagree }\end{array} \\
12\end{array}$} & \multirow{2}{*}{$\begin{array}{r}\text { Disagree } \\
1\end{array}$} & \multirow{2}{*}{$\begin{array}{r}\text { Partially } \\
\text { Agree } \\
6\end{array}$} & \multirow{2}{*}{$\begin{array}{r}\text { Agree } \\
3\end{array}$} & \multirow{2}{*}{$\begin{array}{r}\text { Totally } \\
\text { Agree } \\
13\end{array}$} & \multirow{2}{*}{$\begin{array}{r}{ }^{*} \text { A.M. } \\
3.11\end{array}$} & \multirow{2}{*}{$\begin{array}{r}* * \text { s.d. } \\
1, .\end{array}$} \\
\hline Wastewater is reused after process- & $f$ & & & & & & & \\
\hline n our hotel & $\%$ & 34.3 & 2.9 & 17.1 & 8.6 & 37.1 & & \\
\hline \multirow{2}{*}{$\begin{array}{l}\text { Attention is paid to energy conser- } \\
\text { vation in our hotel. }\end{array}$} & $f$ & 0 & 0 & 1 & 8 & 26 & 4.71 & 0.51 \\
\hline & $\%$ & 0 & 0 & 2.9 & 22.9 & 74.3 & & \\
\hline \multirow{2}{*}{$\begin{array}{l}\text { Hotel employees receive training in } \\
\text { environmental management. }\end{array}$} & $f$ & 1 & 0 & 11 & 10 & 13 & 3.97 & 0.98 \\
\hline & $\%$ & 2.9 & 0 & 31.4 & 28.6 & 37.1 & & \\
\hline \multirow{2}{*}{$\begin{array}{l}\text { Training in environmental man- } \\
\text { agement, human resources will be } \\
\text { provided by employees. }\end{array}$} & $f$ & 11 & 4 & 8 & 5 & 7 & 2.80 & 1.53 \\
\hline & $\%$ & 31.4 & 11 & 22.9 & 14.3 & 20 & & \\
\hline \multirow{2}{*}{$\begin{array}{l}\text { Non-hotel companies are backed } \\
\text { up related to education about } \\
\text { environmental management given } \\
\text { to employees }\end{array}$} & $f$ & 8 & 1 & 6 & 8 & 12 & 3.42 & 1.55 \\
\hline & $\%$ & 22.9 & 2.9 & 17.1 & 22.9 & 34.3 & & \\
\hline \multirow{2}{*}{$\begin{array}{l}\text { The hotel staff is required to receive } \\
\text { to training about environmental } \\
\text { management during their university } \\
\text { studies }\end{array}$} & $f$ & 11 & 2 & 10 & 5 & 7 & 2.85 & 1.51 \\
\hline & $\%$ & 31.4 & 5.7 & 28.6 & 14.3 & 20 & & \\
\hline \multirow{2}{*}{$\begin{array}{l}\text { Our hotel is differentiated by the } \\
\text { importance given to issues related } \\
\text { to environment and environmental } \\
\text { management. }\end{array}$} & $f$ & 0 & 1 & 10 & 13 & 35 & 4.02 & 0.89 \\
\hline & $\%$ & 0 & 2.9 & 28.6 & 31.4 & 37.1 & & \\
\hline \multirow{2}{*}{$\begin{array}{l}\text { Issues about environment and } \\
\text { environmental management in } \\
\text { Turkey are paid enough attention by } \\
\text { the hotels }\end{array}$} & $f$ & 5 & 14 & 12 & 0 & 4 & 2.54 & 1.12 \\
\hline & $\%$ & 14.3 & 40 & 34.3 & 0 & 11.4 & & \\
\hline
\end{tabular}

The arithmetic mean ranges used are given below (Ozdamar, 2003):

${ }^{*}$ Arithmetic Mean Ranges; * ${ }^{*}$ Standard Deviation

Very Low 1 -1.79; Low 1.80 - 2.59; Medium 2.60 - 3.39; High 3.40 - 4.19; Very High 4.20 - 5.00

their employees. 5 star hotels agreed with the statement of "Our hotel is differentiated by the importance given to issues related to the environment and environmental management" with $4.3 \% .3$ star hotels agreed with the statement of "Issues about the environment and environmental management in Turkey are paid enough attention by the hotels" with 4\% . I star hotels did not agree with that statement with I.83\%.

\section{Results and Recommendations}

Tourism includes individual tourists and private groups as well as commercial tours, and travel agents sell packages that include unaccompanied transport, activities and accommodation. Hotels constitute a key element of the organized chain of activity in the trav- 
el and tourism industry, and occupy a crucial place in concerns over environmental protection related to tourism and travel. The hotel industry, because of the nature of its functions, characteristics, and services, consumes substantial quantities of energy, water, and non-durable products. It has been estimated that majority of environmental impacts are created by the hotel industry (Erdogan and Baris, 2007). According to Turkey's Environmental Impact Assessment (EIA) regulation, hotels with $5 \mathrm{O}$ or more guest rooms must prepare an environmental impact assessment report (ÇED, 2003).

Besides, hotels that fulfil all required qualifications are issued with "Eco-Friendly Certificate of Incorporation" (Icon of Pine) by the Ministry of Culture and Tourism for raising environmental awareness, and encouragement of positive contribution of hotels to the environment since I993. In 2008 classification form used in eco-friendly hotels were updated to include issuance of green stars. Green-star hotels are required to fulfil the following basic criteria:

- Having an environmental policy and action plan,

- Being kept authorized who will practice to the action plan in the hotel or taking this service from a professional or professional company with the authorized who is responsible for implementation in the accommodation companies,

- Delivering education to the staff for implementing action plan and environmental precaution, increasing environmental consciousness,

- Presence of eco-friendly waste water plan,

- Keeping record of periodic maintenance and repair of all the outfit, instalment, equipment

- Gathering data on water consumption, energy consumption for heating and cooling, electric consumption, general energy consumption, chemical materials and waste amount.

The hotels that bear "green star" are audited every other year. Hotels are separated into two as holiday and city hotels while scoring. Hotels are assessed under IO topics which are water and energy savings, bedroom arrangements, baths and toilets, detergent and its waste, and over 122 criteria that have a different point. Hitherto 22 hotels have been issued green star by the Ministry (Ministry of Environment and Forestry, 2OI2).

Accordingly, environmental protection precautions are gradually becoming more critical in Turkish tourism. Therefore the necessity of staff that are educated about environmental management is increasing.

In this study, all hotels participated in our survey have practices about environment. Hotels were chosen from among those with a blue flag and most of them have five stars. All of them has practices and accreditation about environmental management. They think the environmental management education is a necessity for tourism. Survey results are an indicator of environmental education necessity.

According to Yeşiltaş et al. (2OIO), the establishment of tourism and hospitality related undergraduate programs by educational institutions through the Ministry of Education was done in a rush to meet the industry's rapidly increasing human resource needs, but without adequate planning, which, in turn, has led to a number of problems including insufficient training, equipment and facilities. Curriculum-related problems reported by vocational secondary schools were linked to limited budgets as well as the lack of coordination and collaboration between the schools

The internationalization of tourism education programs creates an opportunity to complete missing parts in the education systems. Some educational exchange programs like 
ERASMUS, which is under the control of European Commission, gives both students and the instructors a chance to exchange their knowledge with others in different European countries. The number of students in the tourism and leisure subject areas grew from I82 to 700, while the number of participating universities tripled. When other international universities' curricula are observed, the needs of integration of environmental aspects in higher tourism education can be understood easily. From this point of view, missing points in environmental tourism education in a given country can be eliminated by the help of such cooperation (Richards, 1998).

In Turkey, after vocational school, students usually choose to give up university education and start working in tourism sector. On the other hand, even two-year vocational school graduate managers in eco-friendly hotels emphasize the importance of environmental management education. According to survey results, managers with 2-year degree are the most sensitive ones about environmental education. This supports the perspective on the necessity of environmental education themes in higher education for tourism in Turkey.

The awareness about the importance of tourism education has to increase. Because tourism sector's contribution to the balance of payments, elimination of differences in regional development levels and accelerating social development, it continues to be a solution for the increasing unemployment problem especially during the economic crisis. This contribution can also be seen in the Istanbul Chamber of Commerce's data in its publication of $5 \mathrm{OO}$ Big Industrial Organization (ISO 5OO, 2OII). According to the data from a comparative research by Ekin Group Research Unit, those working in industry decreased from 700,000 to 552,000 between $1990-2008$. In the same period, those working only in hotels increased from I67,000 to 319,000, which means I52,000 more people could be employed. Contrary to this reality and the advantage of the tourism sector in providing employment even during crisis periods, regulations and decisions made further enhanced the problems of the sector. It will be wrong to put emphasize to tourism education only for economic reasons. Turkey has significant natural values that are the priority of tourism. The future of tourism depends on these natural resources.

This is why lessons on environmental concern should take place in schools especially in higher education for tourism. Otherwise, it is inevitable losing resource values due to unconsciousness. According to Buckley (2009), environmental management is extremely beneficial for the hotels. For example, it might lead people to consume less water, energy and resources, recycle more, buy more environmentally friendly goods, contribute time or money to conservation efforts of various kinds, or give greater weight to environmental and conservation issues when voting in elections or taking part in other political processes.

The aim of this study is to determine the understanding hotel employers' point of view about aforementioned integration. As can be seen on the results of the survey, integration of environmental aspects in higher education is inevitable.

Human resource plays an essential role in Turkey which has multifaceted development effort. One of the most crucial elements is the quality of tourism services and tourism education level of employers in the tourism sector to improve the quality of service. As consumers recognize the importance of protecting our environment, environmentalism has become a major issue in the tourism marketplace (Brown, 1996). The reports set out as a result of various studies seem to confirm this point. For instance, "Policies will be greener and travellers more environmentally friendly aware" statement is used in "Ten Business Travel Trends for 2OI2" that was published by CWT (Carlson Wagonlit Travel), which is an international travel agency, in $2 \mathrm{OI} 2$ (Koetting and Widener, 2OI2). Accordingly, the increase in the number of 
eco-friendly hotels in Turkey will play a pivotal role in becoming a more preferred destination. Integration of environmental aspects in higher tourism education is crucial.

\section{References}

Academic Tourism Bulletin (2009). Year: IO, Number: 9, September.

Airey, D. and Johnson, S. (I999). The Contents of the Tourism Degree Coursen in UK. Tourism Management, 2O, 229-235.

Ağaoğlu, O K. (I99I). Türkiye'de Turizm Eğitimi ve Etkinliği, Ankara, Milli Prodüktivite Merkezi Yayınları.

Avcıkurt, C. ve Karaman, S. (2002). Lisans Eğitimi Veren Turizm Okullarının Ders Programlarının Karşılaştırılması, Turizm Eğitimi Konferansı-Workshop. Ankara: Turizm Bakanlığı Turizm Eğitimi Genel Müdürlüğü Yayını.

Aymankuy, Y., ve Aymankuy Ş. (20O2). Önlisans ve Lisans Düzeyindeki Turizm Eğitimi veren Yükseköğretim Kurumlarının Bulundukları Yerlerin Analizi ve Turizm Eğitimi için Öneri Bir Model, Turizm Eğitimi Konferansı-Workshop. Ankara: Turizm Bakanlığı Turizm Eğitimi Genel Müdürlüğü Yayını, 29-42.

Barron, P. and Prideaux, B. (1998). Hospitality Education in Tanzania, Journal of Sustainable Tourism 6, 3, 224-237.

Beunders, N., Klep, R., Tapanninen, M. and Gunes, G. (2007). Sustainable Tourism Development Strategy Guideline for Protected Areas of Turkey (In Turkish: Türkiye'deki Korunan Alanlar ve Çevresinde Sürdürülebilir Turizm Gelişim Stratejisi Rehberi). Turkish Ministry of Environment and Forestry, Dumat Ofset Ankara, I2O.

Bircan, İ., Ülker, H.İ., Güneş, G., Karakoç, G. And Poyraz, Z. (2OIO). Tourism Destination Sustainability And Non-Governmental Organizations (NGO's): A Case Study Of Beypazari, Turkey. Journal of Educational Travel I(I), I7-32.

Brown, M. (1996). Environmental policy in the hotel sector: "green" strategy or stratagem? International Journal of Contemporary Hospitality Management, 8/3,I8-23.

Buckley, R. (2009). Ecotourism: Principles and Practices. Wallingford, Oxford: CAB International, 368.

ÇED (20O3). Çevresel Etki Değerlendirmesi Yönetmeliği (Environmental Impact Assessment Act), I6.I2.2003 Tarih ve 253I8 sayılı Resmi Gazete.

Chaineux, M.C.P. and Charlier, R.H. (1999). Strategies in Environmental Education. International Journal of Environmental Studies, 56, 6, 889-905.

Christou, E. (I999). Hospitality management education in Greece: an exploratory study. Tourism Management 2O, 6, 683-692.

Dale, C \& Robinson, N. (2OOI). The Theming of Tourism Education: A Three- Domain Approach. The International Journal of Contemporary Hospitality Management, 3O-34.

Directorate of Tourism and Trade Education, (2OII). Retrieved from http://ttogm.meb.gov. tr/haber.php?go=tamhaber\&haberid $=669$.

DPT (Devlet Planlama Teskilati) (2007). Report of Tourism Commission 9th Programme of Five Year Development (In Turkish: Turizm Ozel İhtisas Komisyonu Raporu- Dokuzuncu Bes Yillik Kalkinma Programi), Ankara.

Eagles, P.F.J., McCool, S. F. and Haynes, C.D. (2OO2). Sustainable Tourism in Protected Areas: Guidelines for Planning and Management. IUCN Gland, Switzerland and Cambridge, UK. I83pp. 
Environmental Education Project (2OII). Retrieved from www.keepnepal.org

Erdogan, N. and Baris, E. (2007). Environmental Protection Programs and Conservation Practices of Hotels in Ankara-Turkey, Tourism Management Journal 28, 604-6I4.

Fidgeon, R.P. (2OIO). Progress in Tourism Management, Tourism education and curriculum design: A time for consolidation and review?, Tourism Management Journal 3I, 699-723.

Hacıoğlu, N., Kaşlı, M.,Şahin, S. ve Tetik, N. (2008). Türkiye’de Turizm Eğitimi, Detay Yayıncılık, Ankara.

Haluzan, N. (2OI2). Environment-Definition and Meaning, Ecological Problems Journal, EU.

Hazar, A. (2OO2). Anadolu Otelcilik ve Turizm Meslek Liseleri ile Anadolu Asçılık Meslek Lisesi Ögretmeni Yetistiren Egitim Fakültelerinin Ögretmen ihtiyaçları Açısından Geliştirilmesi, Turizm Eğitimi Konferansı-Workshop. Ankara: Turizm Bakanlığı Turizm Eğitimi Genel Müdürlüğü Yayını.

Hall, C.M. (2008). Tourism Planning: Policies processes and relationships ( $2^{\text {nd }}$ edition). Harlow: Prentice-Hall.

İAU (2OII). İstanbul Aydın University TURAD 2OIO-2OII Öğrenim Raporu, 2OII, Retrieved from http//www.turad.org/uploads/AUTAM TURADISO 500 Data / ICO (Istanbul Chamber of Industry) 500 Data.

ISO 500 (2OII). Retrieved from http://www.iso.org.tr/tr/web/besyuzbuyuk/turkiye-nin5OO-buyuk-sanayi-kurulusu--iso-500-raporunun-sonuclari.html

Jafari, J. (I997). Tourism and Culture: An Inquiry into Paradoxes Culture, Tourism, Development: Crucial Issues for the XXI Century. Proceedings of a Round Table, Paris.

Koetting, M. and Widener, F. (2OI2). Ten Business Travel Trends for 2OIO. CWTvIsIon, Retrieved fromhttp://www.carlsonwagonlit.com/export/sites/cwt/en/global/tmi/ cwt-perspectives/travel-management-priorities/pdf/travel-spend.pdf

Kusluvan, S. and Kusluvan, Z. (2000). Perceptions and attitudes of undergraduate tourism students towards working in the tourism industry in Turkey, Tourism Management, 2I, 252.

Lockwood, A. and Medlik, S. (2OOI). Tourism and Hospitality in the $2 \mathrm{I}^{\text {st }}$ Century. Butterworth-Heinemann, Oxford, 324.

Kousis, M. (2000). Tourism and the environment: a social movements perspective, Annals of Tourism Research, 27, 2, 468-489.

Ministry of Culture and Tourism (2007). Tourism Strategy of Tukey-2O23. (In Turkish: Turkiye Turizm Stratejisi-2O23), Ankara, 62.

Ministry of Culture and Tourism (2OII). Çevreye Duyarlılık Kampanyası (Yeşil Yıldız). Retrieved from http://www.ktbyatirimisletmeler.gov.tr/belge/I-77587/cevreye-duyarlilik-kampanyasi-yesil-yildiz.html.

Nyberg, R. (I998). Integration of Environmental Aspects In Tourism Education. Project number: MUoI9/95, Council for the Renewal of Higher Education.

Ozdamar, K. (2003). Modern Bilimsel Arastirma Teknikleri, Kaan Kitabevi, Eskisehir, 32.

Ozkaya, I. (2007). A Study on Cultural and Nature Assets (In Turkish: Kultur ve Tabiat Varliklarinin Korunmasi Uzerine Bir İnceleme), Ekoloji Kolektifi, Retrived from http://www. ekolojistler.org/kultur-ve-tabiat-varliklarinin-korunmasi-uzerine-bir-inceleme-3I.html.

Oncuer, M. E. (2006). Avrupa Birliği Eğitim Politikasında mesleki turizm eğitimi yaklaşımı ve Türk Turizm Eğitimine Uygulanabilirliği. Yayımlanmamış Doktora Tezi, İzmir: Dokuz Eylül Üniversitesi Sosyal Bilimler Enstitüsü, Turizm İşletmeciliği Anabilim Dalı.

OSYM (T.C. Ölçme, Seçme ve Yerleştirme Merkezi) (2OI2) 2OI2 Öğrenci Yerleştirme Klavuzu, Retrieved from www.osym.gov.tr. 
Parris, R.G. (1997). Tourism and Cultural Interaction: Issues and Prospects for Sustainable Development Culture, Tourism, Development: Crucial Issues for the XXI Century. Proceedings of a Round Table, June. Paris.

Richards, G. (I998) A European network for tourism education, Tourism Management, I9 (I)

Ruzza, C. (1999) Environmental Sustainability and Tourism in European Policy Making, Ed.K. Eder and M. Kousis, The Europeanization of Environmental Politics: Sustainable Development in Southern Europe, Kluwer Academic Publishers, Dordrecht.

Schmelzkopf, K. (2002). Interdisciplinary, Participatory Learning and Geography of Tourism, Journal of Geography in Higher Education, 26 (2), I8I-I95.

Shrestha, S.K. and Rayamajhi, S. (I997). Role of the Institute of Forestry/Nepal in Ecotourism Education and Development. RECOFTC Report, RECOFTC/FAO, Bangkok (Thailand), 228-234.

The Final Report of The Conference on The Research of Academic Tourism Education (2009), April 22-25, Bodrum,

Tribe, J. (2002). The philosophic practitioner. Annals of Tourism Research 29(2), 338-357.

TUROFED Journal, July (2009), Number:34.

UNWTO (2OII). Tourism Highlights. Retrieved from www.unwto.org.

UNWTO (2OI2). Tourism Highlights. Retrieved from www.unwto.org.

Victurine, R. (2000). Building Tourism Excellence at the Community Level: Capacity Building For..., Journal of Travel Research, 38, 3, 22I-230.

Vlavianos-Arvanitis, A. (1997). 'Biopolitics - Dimensions of Biology' in Biopolitics - The Bio-Environment, Biopolitics International Organisation, Athens, Greece.

Vlavianos-Arvanitis, A. (1998). Biopolitics - The Bios Theory, Biopolitics International Organisation, Athens.

Verbole, P. (2005). The Role of Education in the Management of Rural Tourism and Leisure. New Directions in Rural Tourism, Ed. D.Hall, L. Roberts and M.Mitchell, England: Ashgate, I83-I89.

Wade, J.A. (1999). Students as Environmental Change Agents. International Journal of Contemporary Hospitality Management, II/5, 25I-255.

Yazcayir, N. and Yagci, E. (2009). Vocational and Technical Education in EU Nations and Turkey, Procedia-Social and Behavioral Sciences I, I, IO38-IO42.

Yeşiltaş, M., Öztürk, Y. and Hemminton, N. (2OIO). Tourism Education in Turkey and Implications for Human Resources, Anatolia, 3-I9. 